\title{
François-Marie Mourad, Zola critique littéraire, entre Sainte-Beuve et Taine
}

Chiara Lanciano

\section{(2) OpenEdition}

1 Journals

Édition électronique

URL : http://journals.openedition.org/studifrancesi/9325

DOI : 10.4000/studifrancesi.9325

ISSN : 2427-5856

Éditeur

Rosenberg \& Sellier

\section{Édition imprimée}

Date de publication : 1 juin 2008

Pagination : 221

ISSN : 0039-2944

\section{Référence électronique}

Chiara Lanciano, «François-Marie Mourad, Zola critique littéraire, entre Sainte-Beuve et Taine », Studi Francesi [En ligne], 154 (LII | I) | 2008, mis en ligne le 30 novembre 2015, consulté le 13 janvier 2021. URL : http://journals.openedition.org/studifrancesi/9325; DOI : https://doi.org/10.4000/studifrancesi. 9325

Ce document a été généré automatiquement le 13 janvier 2021.

\section{cc) (1) $\odot$}

Studi Francesi è distribuita con Licenza Creative Commons Attribuzione - Non commerciale - Non opere derivate 4.0 Internazionale. 


\title{
François-Marie Mourad, Zola critique littéraire, entre Sainte-Beuve et Taine
}

\author{
Chiara Lanciano
}

\section{RÉFÉRENCE}

FRANÇOIS-MARIE MOURAD, Zola critique littéraire, entre Sainte-Beuve et Taine, «Revue

d'Histoire Littéraire de la France», 107ème année n. 1, Paris, PUF, janvier 2007, pp.

83-103.

1 Zola critique s'est trouvé dès le début de sa carrière au confluent de Sainte-Beuve et de Taine qu'il place dans son panthéon référentiel. Entre «tentation et imitation, rivalité et dénégation", l'auteur des Rougon-Macquart a tenté de se frayer un chemin entre les deux géants de la critique méthodique et naturaliste: Sainte-Beuve a ouvert la voie à la critique moderne, Taine en est devenu le représentant le plus prestigieux.

2 À partir de l'examen attentif de textes théoriques et critiques de Zola, Francois-Marie Mourad se propose d'analyser les influences qu'ont eues successivement les œuvres et les fréquentations de Sainte-Beuve et de Taine sur la formation critique du jeune courriériste. 